\title{
Karakteristik Pola Gambar Anak Usia Dini
}

\author{
Aini Loita \\ Universitas Muhamadiyah Tasikmalaya \\ aini.loita@umtas.ac.id
}

\begin{abstract}
Abstrak
Menggambar merupakan aktivitas yang disukai oleh anak usia dini. Berbagai perkembangan fisik dan mental terlibat dalam kegiatan menggambar. Sesuai dengan pengalaman jiwanya, anak-anak menggambar sesuatu yang diketahuinya menurut jalan pikirannya yang berbeda dengan pemikiran orang dewasa. Tahapan gambar anak usia dini dimulai dari gambar coreng moreng tak beraturan, terkendali dan coreng moreng bernama. Gambar atau seni lukis karya anak usia dini menjadi unik, imajinatif, jujur, lugas dan naif, berani, juga menunjukkan spontanitas. Disamping sifat-sifat lain yang khas sebagai ungkapan anak, para pendidik dan pengamat seni harus memahami karakter anak usia dini agar setiap proses pembelajaran tepat guna sesuai sasaran pertumbuhan dan perkembangan anak usia dini. Sudah selayaknya menghargai karya anak-anak sesuai dengan fitrahnya dan memberikan peluang sebesar-besarnya untuk mengembangkan potensi dan kreativitas anak dalam berekspresi seni. Proses pendidikan yang dilaksanakan dalam suasana yang menyenangkan maka potensi dan kreativitas anak didik akan tergali secara optimal.
\end{abstract}

Kata Kunci: Karakter, Usia Dini, Gambar.

\begin{abstract}
Drawing is an activity favored by early childhood. A variety of physical and mental developments are involved in drawing activities. In accordance with the experience of his soul, the children draw something he knows according to his way of thinking that is different from that of adults. Early childhood picture stages begin with irregular, controlled scribbles and streaks named. Picture or painting by early childhood to be unique, imaginative, honest, straightforward and naive, brave, also shows spontaneity. In addition to other distinctive traits as the child's expression, art educators and observers must understand the character of early childhood in order that each learning process is appropriate to target the growth and development of early childhood. Should properly appreciate the work of children in accordance with his nature and provide opportunities as much as possible to develop the potential and creativity of children in art expression. The process of education is carried out in a pleasant atmosphere then the potential and creativity of students will be explored optimally.
\end{abstract}

Keywords: Character, Early Childhood, Picture. 


\section{Pendahuluan}

Pendidikan untuk anak usia 0-5 tahun atau biasa disebut dengan pendidikan anak usia dini (PAUD) adalah jenjang pendidikan sebelum jenjang pendidikan dasar yang merupakan suatu pembinaan yang ditujukan bagi anak sejak lahir sampai dengan usia 6 tahun, yang dilakukan melalui pemberian rangsangan pendidikan untuk membantu pertumbuhan perkembangan jasmani dan rohani agar anak memiliki kesiapan dalam memasuki pendidikan lebih lanjut yang diselenggarakan pada jalur formal, non formal dan informal.

Pendidikan anak usia dini merupakan salah satu bentuk penyelenggaraan pendidikan yang menitikberatkan pada peletakan dasar ke arah pertumbuhan dan perkembangan fisik (koordinasi motorik halus dan kasar), kecerdasan (daya pikir, daya cipta, kecerdasan emosi, serta kecerdasan spiritual), sosio emosional (sikap dan perilaku serta agama) bahasa dan komunikasi, sesuai dengan keunikan dan tahap perkembangan yang dilalui oleh anak usia dini.

Dr. Paul Torrance menyatakan kreativitas seseorang mulai meningkat pada usia 3 tahun dan mencapai puncaknya pada usia 4,5 tahun, dimana umumnya akan segera menurun apabila tidak diupayakan agar kemampuan tersebut tetap terus berkembang. Setiap anak dilahirkan dengan potensi yang luar biasa, hanya terkadang orang tua atau pendidik kurang mengasah potensinya tersebut, bahkan cenderung mematikannya. Anak memerlukan stimulasi dan pedoman dari orang tua dan pendidik untuk:

1. Meningkatkan rasa percaya dirinya dan mengurangi rasa takut.

2. Memperkuat keterampilan belajarnya.

3. Membantu mengembangkan hubungan dengan anak-anak lain yang sebayanya.

4. Memperbaiki perkembangan secara keseluruhan.

5. Melibatkan dirinya dalam menentukan tujuan belajar dan evaluasinya.

6. Memberikan pengawasan yang tidak terlalu ketat dan otoriter.

Dalam melaksanakan pendidikan usia dini hendaknya menggunakan prinsip-prinsip sebagai berikut:

1. Berorientasi pada kebutuhan anak; kegiatan pembelajaran pada anak harus senantiasa berorientasi kepada kebutuhan anak, anak usia dini adalah anak yang sedang membutuhkan upaya-upaya pendidikan untuk mencapai optimalisasi semua 
aspek perkembangan fisik maupun psikis, yaitu intelektual, bahasa, motorik dan sosio emosional.

2. Belajar melalui bermain; bermain merupakan sarana belajar anak usia dini. Melalui bermain anak diajak untuk bereksplorasi, menemukan, memanfaatkan dan mengambil kesimpulan mengenai benda disekitarnya.

3. Lingkungan yang kondusif; lingkungan harus diciptakan sedemikian rupa sehingga menarik dan menyenangkan dengan memperhatikan keamanan dan kenyamanan yang mendukung kegiatan belajar melalui bermain.

4. Menggunakan pembelajaran yang terpadu; pembelajaran pada anak usia dini harus menggunakan proses pembelajaran terpadu yang dilakukan melalui tema. Tema yang dibangun harus menarik dan dapat membangkitkan minat anak dan bersifat kontekstual. Hal ini dimaksudkan agar anak mampu mengenal berbagai konsep secara mudah dan jelas sehingga pembelajaran menjadi mudah dan bermakna bagi anak.

5. Mengembangkan berbagai kecakapan hidup; mengembangkan keterampilan hidup dapat dilakukan melalui berbagai proses pembiasaan. Hal ini dimaksudkan agar anak belajar untuk menolong diri sendiri, mandiri dan bertanggung jawab serta memiliki disiplin diri.

6. Menggunakan berbagai media edukatif dan sumber belajar; media dan sumber belajar dapat berasal dari lingkungan alam sekitar atau bahan-bahan yang sengaja disiapkan oleh pendidik.

7. Dilaksanakan secara bertahap dan berulang-ulang; pembelajaran bagi anak usia dini hendaknya dilakukan secara bertahap dimulai dari konsep sederhana dan dekat dengan anak. Agar konsep dapat dikuasai dengan baik hendaknya guru menyajikan kegiatan-kegiatan yang berulang.

Sedangkan untuk membangkitkan motivasi belajar anak, menurut Mulyasa (2003) perlu diperhatikan seagai berikut:

1. Bahwa anak akan belajar lebih giat apabila topik yang dipelajarinya menarik dan berguna bagi dirinya.

2. Tujuan pembelajaran harus disusun dengan jelas dan harus diinformasikan kepada anak sehingga mereka mengetahui tujuan belajar yang hendak dicapai.

3. Anak didik juga dilibatkan dalam penyusunan tersebut. 
4. Anak didik harus selalu diberi tahu tentang hasil belajarnya.

5. Pemberian hadiah dan pujian lebih baik daripada hukuman, namun sewaktu-waktu hukuman juga diperlukan.

6. Manfaatkan sikap-sikap, cita-cita, dan rasa ingin tahu anak.

7. Usahakan untuk memperhatikan perbedaan individual anak seperti: perbedaan kemampuan, latar belakang, dan sikap terhadap sekolah dan subjek tertentu.

8. Usahakan untuk memenuhi kebutuhan anak dengan jalan memperhatikan kondisi fisiknya, rasa aman, menunjukkan bahwa guru peduli terhadap mereka, mengatur pengalaman belajar sedemikian rupa sehingga anak didik memperoleh kepuasan dan penghargaan, serta mengarahkan pengalaman belajar ke arah keberhasilan, sehingga mencapai prestasi dan mempunyai kepercayaan diri.

\section{Pembahasan}

\section{Pola Perkembangan Gambar pada Anak}

Para ahli telah banyak meneliti pola perkembangan gambar anak, diantaranya yang paling sering di rujuk ialah periodesasi gambar anak yang dilakukan oleh Victor Lowenfield dan W. Lambert Brittain (1982) dalam bukunya Creative and Mental Growth. Tetapi sebagaimana diingatkan Tabrani dalam Tarjo (2004) pada dasarnya setiap anak unik, walaupun garis besar perkembangan gambarnya sama. Di samping itu, batas tiap tahap perkembangannya ternyata tidak terlalu tegas.

Tahapan perkembangan gambar anak menurut Lowenfeld (1982) diuraikan sebagai berikut:

\section{a. Tahapan Coreng-Moreng (The Scribbling Stage)}

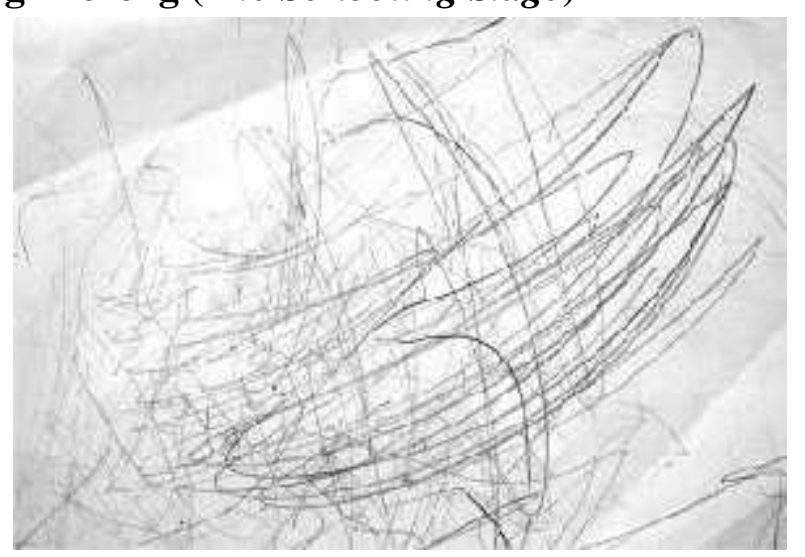

Gambar 1 Gambar Coreng Moreng Tak Beraturan

Sumber: Dokumentasi Aini Loita, 2017 
Tahapan ini berlaku bagi anak berusia 2 sampai 4 tahun (masa pra sekolah). Pada periode ini anak menciptakan goresan coreng-moreng dengan arah yang belum terkendali dan merupakan pengalaman kegiatan motorik. Periode coreng-moreng terbagi dalam tiga tahapan, yakni dari corengan tak beraturan, corengan terkendali, sampai pada tahap corengan bernama. Pada tahap terakhir dari periode ini anak sudah mulai memandang goresannya sebagai gambaran dari orang, gerakan, atau sesuatu yang lain.

\section{b. Tahapan Pra-Skematik (The Preschematic Stage)}

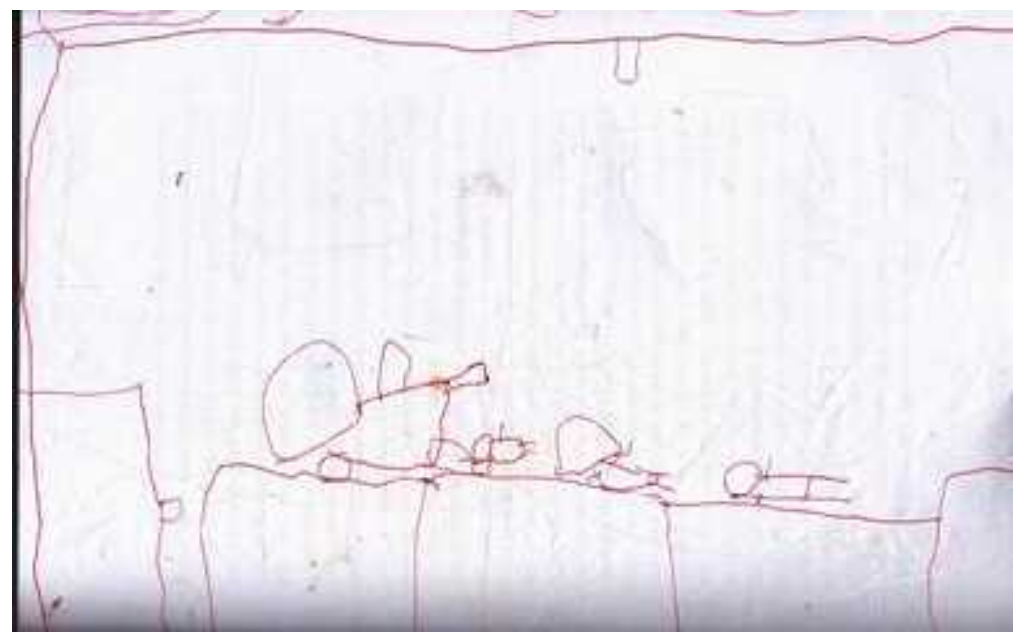

Gambar 2 Gambar Pra-Bagan Anak Usia 4 Tahun

Sumber: Dokumentasi Aini Loita, 2009.

Tahap ini berlaku bagi anak berusia 4 sampai dengan 7 tahun (kurang lebih usia Pendidikan Sekolah Taman Kanak-Kanak). Pada tahap ini anak sudah mulai semakin menguasai gerakan-gerakan tangannya dan telah menyadari adanya hubungan antara bentuk-bentuk yang digambarkannya dengan bentuk-bentuk yang menjadi perhatiannya. Anak membangun ikatan emosional dengan apa yang digambarnya.

Pada mulanya bentuk-bentuk yang diciptakan masih sulit dikenali, yang selanjutnya gambar bersifat geometris mengarah ke bagan. Gambar orang seringkali digambar menjadi bentuk lingkaran sebagai kepala yang langsung dihubungkan dengan beberapa garis untuk tangan atau kaki. Perhatian dan gairah anak lebih tertuju pada hubungan antara gambar dengan obyek dan pada warna dengan obyek. Karena itu warna menjadi subyektif dan tidak mempunyai hubungan tertentu dengan obyek. Pada 
masa ini cara pembimbingannya anak diberi kesempatan untuk aktif mempelajari badan sendiri. Ciri-ciri gambar anak pada tahapan ini yaitu:

- Sudah mulai mengerti hubungan antara gambar, pikiran dan realita.

- Membuat pola-pola garis yang berubah-ubah.

- Taraf mencari konsep, belum ada kemantapan memilih simbol.

- Manusia sebagai kepala kaki.

- Penggambaran ruang hanya secara emosional.

- Perspektif susun.

- Penggunaan warna belum dipakai secara hubungan realita, namun secara emosional.

- Belum mengenal desain.

c. Tahapan Bagan (The Schematic Stage)

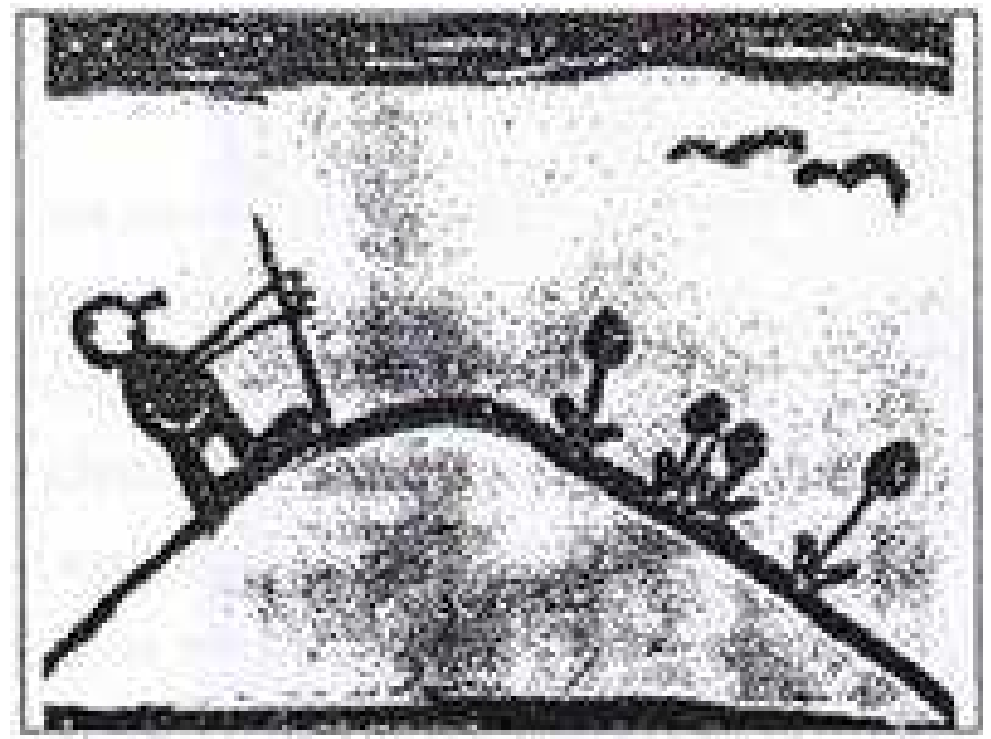

Gambar 3 Gambar Anak Masa Bagan Menampilkan Adegan Mendaki Bukit Sumber: Kellog \& Dell dalam Tarjo, 2004.

Istilah bagan mengacu pada bentuk-bentuk yang diciptakan secara berulangulang. Bentuk-bentuk seperti segitiga, bundar, lonjong, atau segi empat digunakan untuk menggambar tubuh, bagian kaki, tangan, atau pakaian dalam menggambarkan manusia. Pada periode ini terdapat ciri yang menarik pada gambar anak, yakni penggunaan garis dasar atau sejumlah garis dasar tempat menggambarkan obyek-obyek gambarnya berdiri, meskipun ada kalanya tampak terbalik (gambar rebahan). Selain itu juga 
terdapat gejala penggambaran secara tembus pandang (X-ray) yang memperlihatkan sekaligus bagian luar dan dalam sebuah gambar bangunan atau benda lainnya.

Mengenai penggunaan warna sudah mulai terdapat kesadaran anak untuk menghubungkannya dengan warna obyek yang digambar. Periode bagan berlaku bagi anak berusia 7 sampai 9 tahun. Cara pembimbingan gambar pada masa ini sadarkan bahwa anak adalah bagian dari lingkungan dengan mengarahkan ke lingkungan sosial.

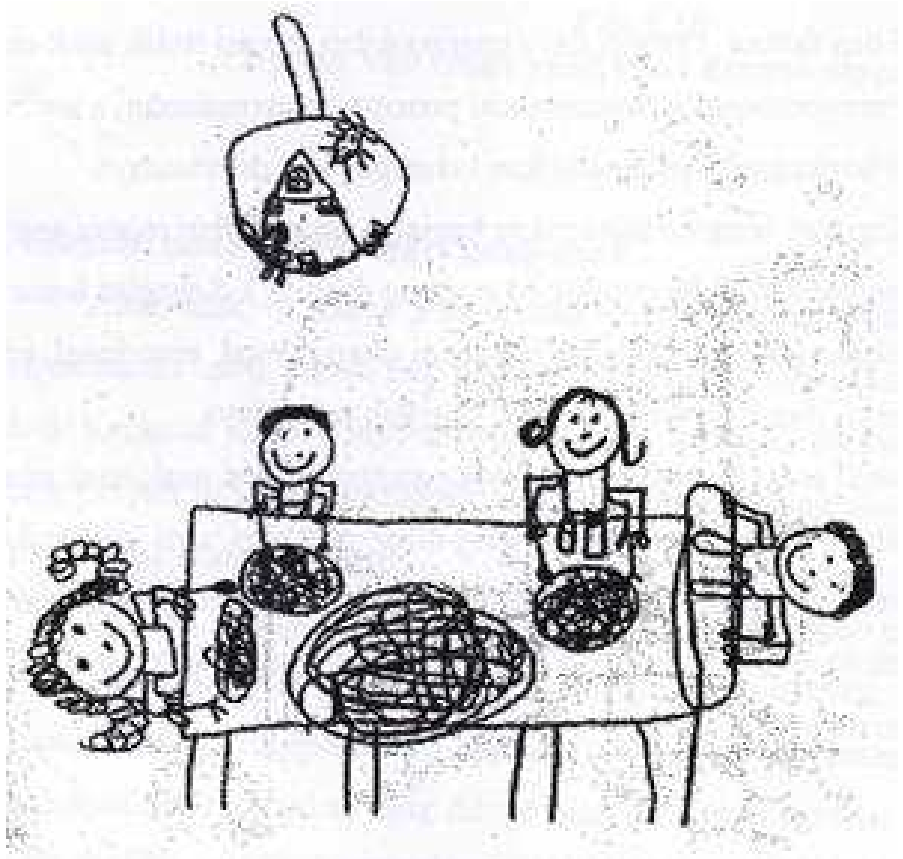

Gambar 4 Gambar Rebahan pada Anak Memiliki Sudut Pandang yang Unik sebagai Manifestasi Rasa Ruang pada Anak Sumber: Viktor Lowenfeld, 1982.

\section{d. Tahapan Permulaan Realisme (The Earlay Realism Stage)}

Tahapan Permulaan Realisme berlaku bagi anak usia 9 sampai 12 tahun. Pada tahap ini, kesadaran visual anak semakin berkembang. Mereka mulai memperhatikan rincian. Terlihat adanya kesadaran untuk menghias atau mengisi obyek gambar. Dalam menggambar orang, ia sudah dapat membedakan gambar laki-laki dan perempuan. Garis-garis dasar ditinggalkan dan diganti dengan bidang untuk menggambarkan konsep ruang. Penggambaran X-ray juga telah disadari sebagai sesuatu yang tak wajar. Meskipun gambar lebih tampak realistis dan tidak berupa bagan, tetapi bukanlah berarti realsitis fotografis. Ajaklah anak ke obyek-obyek yang sifatnya datar, misalnya pola hias, ornamen atau kerajinan. Ciri-ciri gambar anak pada tahap ini yaitu: 
- Sudah mengenal realita.

- Tidak puas dengan skematis, namun untuk menggambarkannya belum bisa.

- Untuk menutupi kekurangan dalam menggambar orang, maka menampilkan bentuk pakaian yang sifatnya masih kaku.

- Untuk menyatakan ruang sudah menggambarkan ekspresi garis dasar.

- Mengerti sifat tutup menutup.

- Mengerti sifat tanah lapang.

- Mengerti garis-garis langit.

- Menggunakan warna secara subyektif emosional yang biasanya dihubungkan dengan pengalaman.

- Dengan sadar sudah membuat rencana.

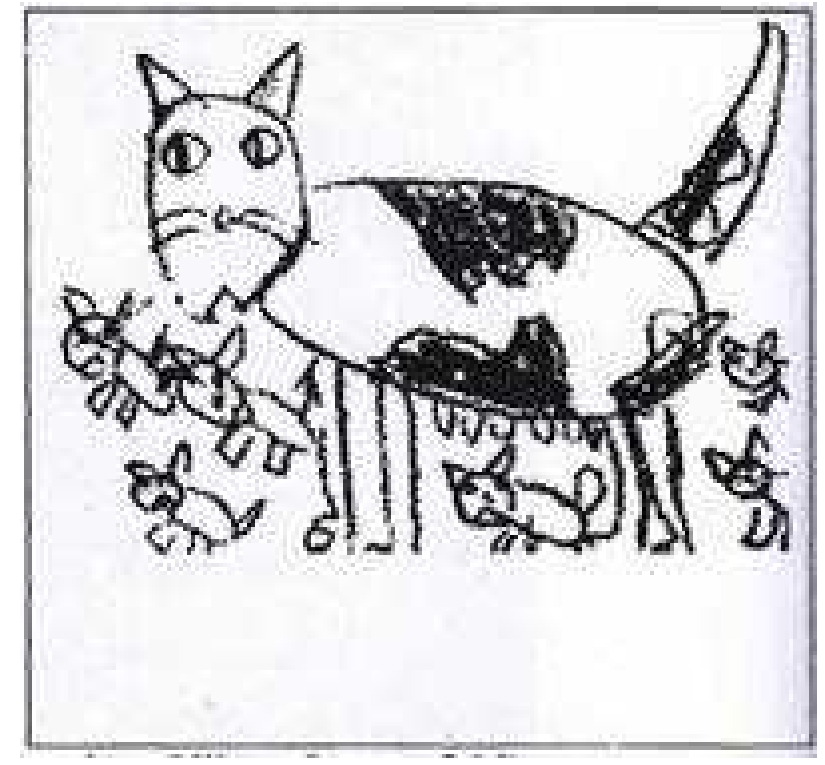

Gambar 5 Gambar Anak pada Tahap Permulaan Realisme

Sumber: Viktor Lowenfeld, 1982

\section{e. Tahapan Naturalistik Semu (The Pseudo-Naturalistic Stage)}

Naturalistik atau realisme semu merupakan periode bagi anak berusia 12 sampai 14 tahun. Pada periode ini, anak menjadi kritis terhadap karyanya sendiri, dan kegiatan menggambar merupakan akhir dari kegiatan spontan. Tahap ini merupakan masa krisis, oleh Tabrani dipandang sebagai saat terjadi perang antara kemampuan indera mata yang telah jadi dengan indera-indera lainnya. Dalam periode ini muncul gambar yang tumpang tindih dan mulai tumbuh kesadaran bahwa ruang mempunyai kualitas tiga dimensi. 
Pada periode ini terdapat dua tipe ungkapan yang berbeda, yakni tipe visual dan haptik, tetapi yang lebih umum ialah tipe campuran dari keduanya. Pada tipe visual, anak peka terhadap kenyataan visual dan cenderung untuk menggambarkan obyek sebagaimana penampakan obyek tersebut. Sebaliknya, pada tipe haptik, tidak menampakkan penggambaran obyek sebagaimana mata melihatnya, melainkan lebih bersifat pribadi, khas, dan subyektif. Oleh karena itu pemahaman perspektif yang diberikan anak pada tahapan ini perlu dilakukan secara hati-hati, sebab tidak semua anak mungkin memerlukannya dan justru dapat menghilangkan minatnya.

Anak dengan tipe visual mengarah ke realis dan cepat mengenal kesan ruang dan kesan garis kaki langit, penggunaan warna mengutamakan kesesuaian obyek dengan suasana. Sedang anak dengan tipe non visual agak sulit ke arah realis sehingga kesan-kesan mendatar lebih menonjol, penggunaan warna sering tidak sesuai dengan obyeknya. Biasanya bersifat simbolik.

\section{f. Masa Anak-anak Puber}

Gambar anak pada masa puber memiliki ciri-ciri mempunyai kesadaran kritis terhadap lingkungan mereka memiliki keberanian mengungkapkan pendapat. Antara tipe visual non visual tampak jelas. Tipe visual mengutamakan proporsi, cahaya dan bayangan. Ruang secara perspektif kosntruktif baik. Warna secara realita persepektif warna. Mengarah ke aliran realis. Sedang tipe non visual penghayatan sepenuh pribadi, menggunakan perasaan simbolisme, warna sesuai dengan ekspresi dan emosi. Mengarah ke dekoratif.

\section{Pola Perkembangan Gambar Usia Dini}

Anak-anak terutama usia dini dimana pun senang kepada menggambar atau membentuk dengan bahan lunak (tanah liat dan lilin), menggunting, melipat atau menyusun kertas bekas. Kegiatan tersebut merupakan kegiatan bermain. Menggambar adalah kegiatan seni rupa yang cenderung paling digemari oleh anak usia dini. Seorang ahli Piere Duquet (1953) menyatakan bahwa anak yang tidak senang menggambar tergolong kepada berkelainan (anomali). Mereka bisa menghabiskan waktu yang banyak untuk kegiatan ini.

Dalam tahap pertama anak menggambar dengan garis dan bentuk dengan bermacam-macam variasi. Sebagai kegiatan kreatif biasa dilakukan dengan main-main atau coreng-moreng, dan apabila hasilnya dikatakan bagus mereka akan lebih 
bersemangat dan ingin mencoba lagi sampai bagus. Sebaliknya apabila dikatakan jelek maka semangat dan pertumbuhan kreativitasnya menjadi hilang. Maka dari itu pemberian dukungan berupa hadiah pujian menjadi sangat penting dalam setiap perkembangannya.

Berbagai isi gambar pada anak seakan muncul secara tiba-tiba tanpa direnungkan dan dipikirkan. Gambar menjadi indah karena unsur naif kekanak-kanakan yang masih terlihat, hal semacam ini biasanya sering muncul dalam setiap lomba gambar anak-anak. Ekspresi memegang peranan penting dalam kegiatan kreatif anak. Dari kebebasan inilah muncul jiwa yang kreatif, yang merupakan pencerminan pribadinya. Pengungkapan rasa kreativitas dalam berkarya sangat dipengaruhi oleh ekspresi jiwanya yang merupakan realitas bentuk kreasi yang sesuai dengan nalurinya.

Anak-anak yang kreatif pada umumnya menghasilkan karya-karya yang ritmis, bebas dan kaya akan variasi akan pengalaman yang dialaminya sehingga mempunyai motivasi untuk berkarya secara kreatif. Masa kanak-kanak adalah masa yang paling subur dalam pengembangan kreativitas. Masa yang tidak terikat oleh aturan-aturan di masyarakat sehingga melahirkan ungkapan yang orisinil.

Gambar anak berusia 2 sampai 4 tahun (masa pra sekolah) berada pada tahapantahapan Coreng-Moreng (The Scribbling Stage). Pada periode ini anak menciptakan goresan coreng-moreng dengan arah yang belum terkendali dan merupakan pengalaman kegiatan motorik. Periode coreng-moreng terbagi dalam tiga tahapan, yakni dari corengan tak beraturan, corengan terkendali, sampai pada tahap corengan bernama. Pada tahap terakhir dari periode ini anak sudah mulai memandang goresannya sebagai gambaran dari orang, gerakan, atau sesuatu yang lain.

Ciri gambar yang dihasilkan anak pada tahap corengan tak beraturan adalah bentuk gambar yang sembarang, mencoreng tanpa melihat ke kertas, belum dapat membuat corengan berupa lingkaran dan memiliki semangat yang tinggi. Corengan terkendali ditandai dengan kemampuan anak menemukan kendali visualnya terhadap coretan yang dibuatnya. Hal ini tercipta dengan telah adanya kerjasama antara koordinasi antara perkembangan visual dengan perkembangan motorik. Hal ini terbukti dengan adanya pengulangan coretan garis baik yang horizontal, vertikal, lengkung, bahkan lingkaran. 
Corengan bernama merupakan tahap akhir masa coreng moreng. Biasanya terjadi menjelang usia 3-4 tahun, sejalan dengan perkembangan bahasanya anak mulai mengontrol goresannya bahkan telah memberinya nama, misalnya: “ibu”, "rumah", "motor", "kucing". Hal ini dapat digunakan oleh orang tua atau guru pada jenjang pendidikan usia dini dalam membangkitkan keberanianan anak untuk mengemukakan kata-kata tertentu atau pendapat tertentu berdasarkan hal yang digambarkannya. Oleh karena itu selain dijadikan sebagai media pendidikan, seni bagi setiap individu sangat bermanfaat karena memberikan kontribusi terhadap perkembangan individu, memberikan pengalaman yang berharga (pengalaman estetik), sebagai bagian yang penting dari kebudayaan.

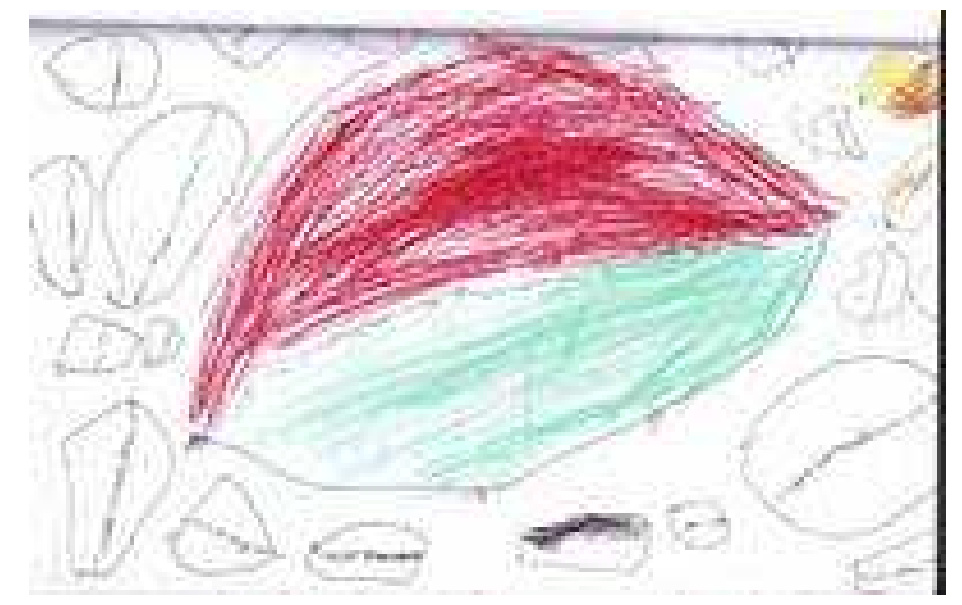

Gambar 1.6 Gambar Coreng Moreng Anak Usia 4 Tahun Tampak Goresan Corengan

Sudah Mulai Terkendali dan Bernama

Sumber: Dokumentasi Aini Loita, 2009

Dengan memperhatikan gambar-gambar yang dibuat anak-anak, para ahli melihat adanya unsur-unsur yang menarik dalam goresan, penempatan objek maupun bentuk penggambaran objek. Psikologi perkembangan melihat adanya keterkaitan antara gambar yang dibuat anak dengan tahap usia perkembangannya. Selain dari itu, ada juga perbedaan-perbedaan individual maupun kelompok. Ada hasil karya yang memperlihatkan kekayaan fantasi, ada pula yang miskin fantasi, ada gambar yang mirip dengan objek aslinya, ada yang sangat berbeda.

Bagi anak kecil seni merupakan sarana bermain, penyalur ekspresi-fantasi, bahasa rupa pada saat kemampuan berbahasa verbal belum berkembang. Italo L. De Francesco (1958) menyatakan bahwa pendidikan seni mempunyai kontribusi terhadap 
pengembangan individual antara lain membantu pengembangan mental, emosional, kreativitas, estetika, sosial, dan fisik.

Seni sebagai kegiatan bermain menempati kedudukan yang sangat penting dalam pendidikan umum. Piere Duquet (1953) menegaskan bahwa anak-anak yang berusia dibawah 10 tahun berada pada masa yang disebut masa keemasan dalam kemampuan berekspresi (the golden age of creative expression). Ekspresi artistik merupakan salah satu kebutuhan anak-anak, oleh karena itu kebebasan berkarya dengan berbagai media dan metode pada kegiatan seni anak-anak menjadi pendekatan utama dalam pendidikan seni rupa anak usia dini. Hal ini memberi manfaat dalam memahami karakteristik perkembangan gambar anak usia dini.

Anak menggambar berdasarkan apa yang diketahuinya (Gaitskell dan Hurwitz, 1975) bukan berdasar apa yang tampak secara visual dari suatu sudut pandang atau persfektif tertentu. Persepsi visual anak menyerupai persepsi orang-orang primitif. Anak-anak (dibawah usia 10 tahun termasuk usia dini) senang sekali bermain bersamasama temannya atau bermain sendiri. Mereka bermain sambil berbicara, berpura-pura seperti orang dewasa. Betapa asyiknya anak-anak itu bermain rumah-rumah, bermain mobil-mobilan dan aneka permainan yang disukainya. Mereka menirukan gerak-gerik dan perilaku orang tuanya dalam kehidupan rumah tangga sehari-hari.

Benda-benda yang tidak terpakai lagi seperti kotak makanan, kotak sabun, dan berbagai macam peralatan sederhana yang mudah dijumpainya di rumah dijadikannya sebagai teman bermain. Benda-benda mati itu dianggapnya sebagai benda yang hidup dan bisa diajak bicara. Anak-anak dalam dunianya itu penuh imajinasi dan fantasi. Dengan daya imajinasi dan fantasi itulah anak-anak juga mampu mengembangkan kemampuan penciptaan permainannya sesuai dengan pengaruh lingkungan dan pendidikan keluarga yang diterimanya terutama dalam kegiatan menggambar.

Aktivitas dalam setiap permainan tersebut tak jarang dijadikan objek berkarya menggambar. Biasanya setiap gambar memiliki arti atau cerita khusus bagi anak. Karena mereka menggambar sambil berfantasi dan berimajinasi. Kegiatan bermain merupakan kegiatan jasmani dan rohani yang penting untuk diperhatikan oleh pendidik (orang dewasa). Sebagian besar perkembangan kepribadian anak, misalnya sikap mental, emosional, kreativitas, etika, sosial, dan fisik dibentuk oleh kegiatan permainannya. 
Permainan anak-anak yang bernilai edukatif dapat dilakukan melalui kegiatan seni, khususnya seni rupa. Pada dasarnya seni adalah permainan yang memberikan kesenangan batin (rohani), baik bagi yang berkarya seni maupun bagi yang menikmatinya (Rohidi, 2000). Anak-anak selama masih tidur penalarannya sangat bergairah berkarya seni karena kegiatan bermain seni memberikan keleluasaan dan kebebasan bagi anak-anak untuk mengungkapkan perasaan atau berekspresi. Ketika penalarannya bangkit, seni harus dipersiapkan untuk memberikan jalan baginya yang akan diterimanya sebagai kegiatan yang disenanginya (Read, 1970:283). Oleh karena itulah seni dijadikan sebagai media pendidikan dan sangat berfaedah.

\section{Simpulan}

Menggambar merupakan salah satu kegiatan seni rupa yang disukai anak usia dini. Hampir setiap anak yang diberi alat tulis pasti digoreskannya pada bidang kosong. Jika diberi kertas, dia akan menggoreskannya pada kertas dengan sesuka hati. Jika tidak diberikan kertas, dia akan menggoreskannya pada dinding atau lantai rumah.

Keasyikan menggambar anak-anak itu merupakan bukti bahwa menggambar baginya sangat memuaskan dan menyenangkan perasaan. Menggambar bagi anak-anak dapat juga menjadi alat berkomunikasi dan berekspresi yang utuh sesuai dunianya. Gambar mulai dari coreng moreng tak beraturan, terkendali hingga coreng moreng bernama seperti manusia, benda-benda di sekelilingnya serta aneka flora dan fauna kesenangannya adalah sebagai hasil ekspresinya dan menjadi media berkomunikasi dengan orang lain (sebagai simbol bahasa).

Sesuai dengan pengalaman jiwanya, anak-anak usia dini menggambar sesuatu yang diketahuinya menurut jalan pikirannya yang berbeda dengan pemikiran orang dewasa. Gambar atau seni lukis karya anak-anak menjadi unik, imajinatif, jujur, lugas dan naif, berani, dan menunjukkan spontanitas, di samping sifat-sifat lain yang khas sebagai ungkapan anak.

Para pendidik dan pengamat seni harus memahami karakter anak usia dini agar setiap proses pembelajaran tepat guna sesuai sasaran pertumbuhan dan perkembangan anak usia dini. Sudah selayaknya kita mengharagai karya anak-anak sesuai dengan fitrahnya dan memberikan peluang sebesar-besarnya untuk mengembangkan potensi dan kreativitas anak dalam berekspresi seni. 


\section{Daftar Pustaka}

Duquet, Piere. (1953). "Creative Communication". Education and Art.A Symposium. Paris: UNESCO.

Francesco, Italo L de. (1958). Art Education Its Means and Ends. New York: Harper \& Brothers.

Gaitskell, C. dan Hurwitz, A. (1975). Chlidren and Their Art. New York: Harcourt Brace Jovanovich.

Lowenfield, Victor \& Brittain LW. (1982). Creative and Mental Growth. London: MacMillan Publ.Co.Inc.

Mulyasa, E. (2003). Kurikulum Berbasis Kompetensi. Bandung: Remaja Rosdakarya.

Read, Herbert. (1970). Education Through Art. London: Faber and Faber.

Rohidi TR. (2000). Kesenian dalam Pendekatan Kebudayaan. Bandung: STISI Press.

Tarjo, E . (2004). Strategi Belajar Mengajar Seni Rupa. Bandung: tidak diterbitkan. 